\title{
Measuring Urban Space of Flows in Information Era: Empirical Evidence from Nanjing, China
}

\author{
Guangliang $\mathrm{Xi}^{1}$, Feng Zhen ${ }^{1 *}$ and Enyu Chang ${ }^{1}$ \\ 1 School of Architecture and Urban Planning, Nanjing University \\ * Corresponding Author, Email: zhenfeng@nju.edu.cn
}

Received: December 13, 2015; Accepted: April 7, 2016

Key words: ICTs, space of flows, spatial mobility, information era, Nanjing

\begin{abstract}
In the information era, the comprehension of space of flows has turned from elemental flows into a combination of technologies, activities and physical spaces with the perspective of a new mobility paradigm. However, how to measure space of flows is still an under-established issue in scholarly discussion. This paper aims to explore the evaluation methods of spatial mobility considering technological accessibility, intensity of activity and spatial activeness. By using residential activity dairies, the present Nanjing traffic system and land use, the spatial mobility of Nanjing was evaluated. The measurement results suggest the extent to which the space of flows affects the space of places, which is critical for understanding urban spatial reconstruction in the information era.
\end{abstract}

\section{INTRODUCTION}

Information and communication technologies (ICTs) are becoming more and more important in reshaping urban societies, for example, by changing traditional understandings of space. The wide application of mobile terminal devices not only changes the mode of production, but also impacts consumption activities. The use of ICTs has different effects on residents' activities. Previous studies have identified four relationships between ICTs and residents' activities: substitution, complementarity, modification and neutrality (Mokhtarian, 1990; Salomon, 1986). ICTs alleviate the temporal and spatial constraints of activities, which decompose the traditional activity into several sub-activity fragments, and reallocate them into different times and places (Couclelis, 2000, 2004). ICTs also enhance activity mobility to a large extent. Due to the in-depth development of information technologies accelerating the element flows (e.g., people flow, material flow, information flow, capital flow, etc.) generated by urban activities, the mode, intensity and connection of residents and their activities' mobility leads to all kinds of "flows" being altered fundamentally, thus the spatial mobility is reinforced greatly. Meanwhile, the construction of rapid traffic networks (e.g., highspeed rail, interurban railway, subway, etc.) and smart cities also improves spatial mobility by compressing the interaction distance between different places.

Under the influence of information technologies, fixed locations and space become more mobile than ever. The relationship between cyberspace and 
physical space also undergoes change, which is crucial to understanding the spatial transformation and the emergence of new spatial form. This transformation could be interpreted from three aspects. Firstly, residents' behavior is no longer constrained by traditional space. For instance, abundant activities (e.g., online shopping, telecommuting, online entertainment, etc.) occur at home and the function of home has been redefined (Hjorthol \& Gripsrud, 2009; Ohmori \& Harata, 2008; Zhen \& Wei, 2008). ICTs improve the tempo-spatial flexibility of residents' activities and lead to changes in the relationship between activities and places. Secondly, the interaction between cyberspace and the physical space changes the meaning of places continually, which makes rigid space turn into flexible space (Kellerman, 2010). Thirdly, production and consumption factors are increasingly exchanged worldwide. The integration of global production flows and localization brings new changes for the organization of urban space as well as spatial mobility ( $\mathrm{Li}$, 2011).

Basically, the concept of the space of flows is given on the grounds of the urban informational transformation. Researchers intensively discussed the "death of distance" and the "end of geography" caused by ICTs and virtual flows in the 1990s (Cairncross, 2001; O'Brien, 1992), and most of them agreed that mobility became the new organizational logic of urban space based on the altering of activity time and space by ICTs. From the insights of sociology, Castells (1989) put forward the concept of the "space of flows" and pointed out that the space of flows was the material organization of time-sharing social practices that worked through mobility in an information society. $\mathrm{He}$ distinguished the "space of flows" and the "space of places", and then explained that there was an obvious difference between the space connected with the virtual network and the space created by daily life (Castells, 1996). Subsequently, the space of flows was extended to the physical space (the space of places) from pure cyberspace. The space of flows can be treated as the result of a combination of cyberspace and the space of places, which is a distinct approach to understand the mobility and transformation of urban form in the information era.

Measuring the space of flows is a critical approach to understand its influence on the space of places in an information society. The space of flows not only accelerates the interchange of element flows across time and space and amplifies the scope of urban production activity and residents' daily activity, but also reshapes the interactions and relationships between different spaces of places. The time-space compression was considered as the most important means to realize the flexible space accumulation in post-modern society (Harvey, 1989). The measurement of the space of flows could be used to reflect the extent of flexible accumulation. Meanwhile, the space of flows, playing a critical role for revitalizing rigid land use and improving spatial activity, becomes more and more important for urban planning. So measuring the space of flows could help to shed light on the extent to which the physical space is changed under the usage of ICTs. The existing measurement of space of flows mainly focuses on the analysis of relationships of individual flows at global and regional scales (Sassen, 2001; Taylor et al., 2007), but measuring the space of flows at the city scale is insufficient.

The aim of this paper is to propose a new approach to measure urban space of flows from the perspective of coupling cyberspace with the space of places. Three dimensions, accessibility, intensity of residential activity and spatial activeness are used to measure the space of flows in Nanjing. The following section is a literature review. Section 3 proposes a framework of urban space of flows and establishes a methodology to measure it, which will then be 
empirically examined in Section 4. The final section will be the conclusion and discussion.

\section{LITERATURE REVIEW}

\subsection{The Mobility Turn: from element flows to the space of flows}

ICTs have led to a global time-space compression which has made social production modes turn into flexible production and accumulation (Harvey, 1989), so factor flows and mobility have changed greatly. Kitchin (1997) emphasized the changing mobility of economic activities under the impact of ICTs, and the mobility of production and consumption activity nodes changed correspondingly. Virtual information flows could enhance the mobility of substantial elements (Kellerman, 2010). The progress of ICTs not only changes the mobility of material elements, but also has a certain impact on the resident's activity mobility. ICTs alleviate the connection of activities with time and space and decompose the individual activity into several fragments (Alexander et al., 2011; Couclelis, 2004) which changes the tempo-spatial mobility of activities. Based on the changing of activity mobility in the information era, Graham and Marvin (2001) and Urry (2000) put forward the concepts of 'splintering urbanism' and 'instantaneous time', respectively.

In addition, ICTs enhance the interaction between element flows and localization of place. Based on the interaction of element flows and localization of space in the information era, Urry (2008) put forward the idea of "mobility turn" and the new mobility paradigm. The new mobility paradigm stresses the combination of technologies, activities and local place, as well as the integration of cyberspace and physical space. Several concepts have been explored to interpret the result of integration, such as "Geocyberspace" (Bakis \& Roche, 1997), "the combination of virtual and physical space" (Graham, 2004) and "Hybrid space" (e Silva, 2006). However, most researchers have agreed upon the concept of the "space of flows" (Bush \& Oosterveer, 2007; Castells, 1989; Shen, 2010). The space of flows could be taken as the most appropriate expression of spatial transformation under the new mobility paradigm in the information era. In the beginning, Castells (2000, 2005) distinguished the space of flows and the space of places, then he began to emphasize the combination of the space of flows and the space of places). This combination has obvious effect on urban function, form and the meaning of place, and changes the connotation of the space of flows representing the virtual network space.

\subsection{Measurement of the space of flows}

Studies on the global space of flows based on connectivity provides a theoretical foundation and empirical method for world city network research. With this argument, the Globalization and World Cities Research Network (GaWK) focused on global city networks. Beaverstock et al. (2000) put forward methodologies to measure the connections between world cities using the data of business news, skilled inter-city migration and the geographical scope of producer services. Based on the division of global production, Alderson and Beckfield (2004) and Taylor (2004a) and Taylor et al. (2007) analysed the network connectivity between world cities through measuring 
the importance of producer services and NGOs. Using the interlocking network model, global network relationships were built with the technological infrastructure connections of world cities (for example, Telecom network, internet, etc.) to display the system structure of city networks (Derudder \& Witlox, 2005; Malecki, 2002; Sassen, 2001; Smith \& Timberlake, 1995). The global space of flows raised global production organization and the networking of global cities (Taylor, 2004b), and it results in the agglomeration and diffusion of nodes in global city networks (Leng \& Yang, 2012). The measurement of global space of flows aims to reveal the impact of globalization (or informatization) on the local space.

Meanwhile, a lot of researchers have focused on the measurement of the regional space of flows with advanced producer services, people flows and communication and high-speed railway networks to reflect the structure of urban systems in America, Europe and China (Dong, Xiu, \& Wei, 2014; Sokol, 2007; Wu, Fang, \& Zhao, 2013; Zhen et al., 2013). The mega-city regions of Europe were measured with a spatial interaction analysis of transportation flows, commuting flows and telecom flows to estimate the coreperipheral structure and the polycentric metropolis (Hall \& Pain, 2006). In addition, social networks, regression models and the Barabasi-Albert model have been employed to analyse regional space structure (Bailey, Allen, \& Bras, 2004). In all, the researchers have tried to reveal the global and regional city networks and structural systems by measuring the connections and interactions of element flows between different cities.

In the information era, residents' mobility reflects much about urban space

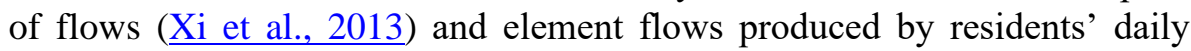
activities play a critical role in shaping urban space. Based on the time geography, researchers have intensively focused on the space-time accessibility and mobility of residents' activities (Kwan, 2013). Hägerstraand (1970) put forward the concept of space-time prisms to analyse individual behaviour and activities. Since then, some new methods, such as using activity diary surveys, GPS, smart phone and others, have been employed to obtain residential behaviour trajectories and analyse individual mobility (Kwan, 2004). The quantitative methods of the structural equation model (SEM) and regression model have been used to analyse the relationship between personal socio-economic attributes, ICT usage, spatial location, the built environment and behaviour (Wang, D. G. \& Law, 2007). Meanwhile, several concepts, such as flexibility, multi-tasking and fragmentation, have been used to measure the tempo-spatial distribution and mobility of resident activities (Alexander, Ettema, \& Dijst, 2010; Maeng \& Nedović-Budić, 2008). Additional analysis on activity space and big data could be used to help to understand urban space of flows from the activity-mobility perspective (Zhao \& Chai, 2013; Wilson \& Graham, 2013).

In conclusion, the existing measurement of space of flows was mainly conducted through flow analysis and the activity analysis of residents who bear all kinds of flows. Different from the space of flows constituted by the production and management of computer networks (Castells, 1989), the new mobility paradigm emphasizes the system coupling of technologies, activities and physical space. However, understanding the space of flows from the new mobility paradigm, which reflects the interaction of cyberspace and physical space, is crucial for reshaping the space of places in an information society. As Figure 1 shows, technologies, institutions, activities and place are the four critical factors in analysing urban space of flows. Technologies (for example, ICTs, transportation, etc.) bring about space-time compression and change the mobility of activities, which integrates the cyberspace and physical space into 
the space of flows through the interaction of the virtual activities and physical activities. This is an important approach to understand the space of flows based on the new mobility paradigm in an information society. The current measurements of the space of flows are mainly referring to the connectivity of production elements and the mobility of residents' activities. However, the space of flows according to the new mobility paradigm needs to be reconsidered and a new methodology for measuring it established. This paper represents a modest attempt to fill such a gap. Specifically, examining how to measure urban space of flows by evaluating spatial mobility. This paper tries to shed light on this through an empirical study of Nanjing, China.

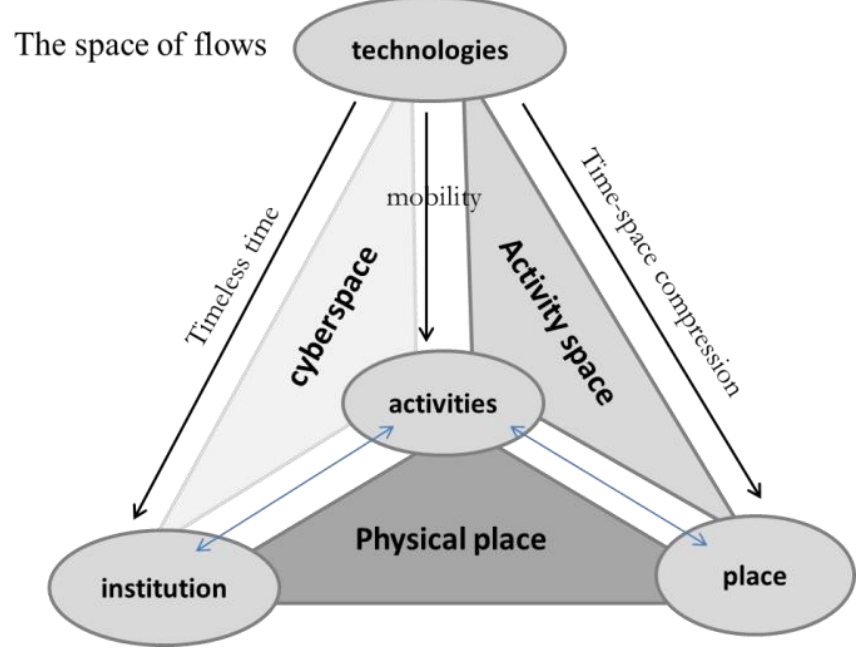

Figure 1. The logical analysis framework of space of flows

\section{RESEARCH DESIGN}

\subsection{The research framework of urban space of flows}

With the new mobility paradigm of an information society, the space of flows could be considered as superimposing residential activities, socioeconomic interaction and the element flows upon physical space. This paper puts forward a new framework of spatial mobility to measure urban space of flows from three aspects, including technological accessibility, intensity of activity and spatial activeness (see Figure 2). The spatial mobility, which decides the organizational structure of the element flows, network and places within the space of flows, also shapes the boundary and scale of the space of flows through the dynamic changing of technological accessibility, activity intensity and spatial activeness at different times and spaces.

Most studies on spatial form and structure generalize the space as point, line and plane from the perspective of geometry. Shen (2010) adopted geometric features in analysing the structure of regional space of flows and considered that cities were the nodes of space of flows, the linear features were the transportation, information network, energy and other flows, and the plane elements of the space of flows included elite space, new industrial space and new urban space. Considering the three aspects of the spatial mobility and their role in constructing the space of flows, this paper distinguishes urban space of flows as consisting of the nodes of place, the route of flows, the boundary of flows, the network of flows and the functional zones. The nodes of urban space of flows are the different urban activity centres. The routes 
represent the direction and intensity of flows, and all the routes and nodes form the network of flows. The boundaries reflect the recession threshold of spatial mobility. The functional zones of the urban space of flows include the residential district, innovation space, recreation space production space, and so on.

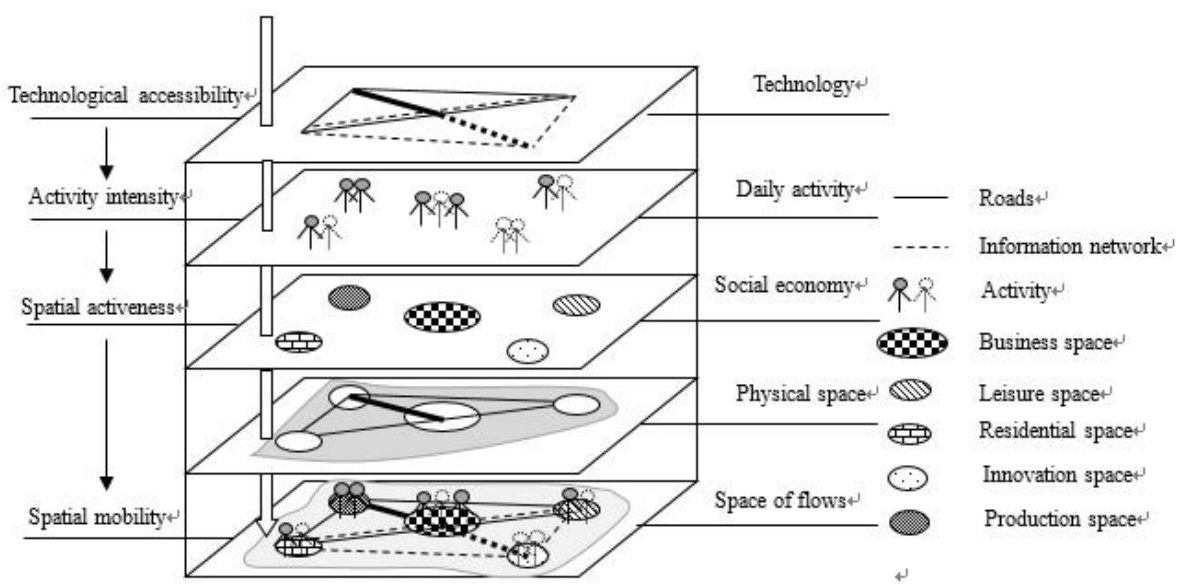

Figure 2. The hierarchy constitution of urban space of flows

\subsection{Methodology}

\subsubsection{Data collection}

A 2-day activity diary which was completed by 980 respondents was surveyed from September to October in 2012 in Nanjing, China. The research team selected 20 activity centres and randomly selected $40-60$ people to whom they administered the survey at each centre. The activity diary was designed to enable each respondent to record the activities in which they participated during the most recent weekday and most recent weekend, including the types of physical and virtual activities in which they engaged during each period, the precise locations where the activities took place, and the type of activity location. We selected 642 effective samples to analyse the activity intensity. Meanwhile, details of the Nanjing traffic system and land use was obtained from the master plan of Nanjing City (2011-2030) ${ }^{1}$.

\subsubsection{Index system for evaluating the spatial mobility}

This paper establishes an evaluation index system from three aspects, spatial accessibilities, the intensity of activity and spatial activeness.

(1) Spatial accessibility. The space of flows is the result of the interaction between cyberspace and the physical space. Its spatial accessibility includes the information access of cyberspace and the transportation accessibility of the physical space, so these two aspects are used to reflect the spatial accessibility. A measurement method of road importance is adopted to calculate the transportation accessibility. Different grade roads, such as railway stations, metro stations, highway roads, main roads and minor roads, are chosen to conduct a buffer analysis, then the results of transportation accessibility are evaluated through overlaying different buffers. According to the degree of effect of different roads on the activities of the surrounding area,

\footnotetext{
${ }^{1}$ Source: Nanjing Urban Planning Bureau. The Master Plan of Nanjing City (2011-2030).
} 
the boundaries of the buffer are defined and different values are given. Individual usage of ICTs, which were measured with the usage of information equipment, internet usage and network application, were used to represent the level of informatization. Then, the informatization level of different spatial units (sub-districts) was obtained based on the average value of individual usage of ICTs. The question of whether respondents "usually use smart phone or not", "usually use laptop or not" and "usually use Pad or not" was chosen to reflect the usage of information equipment, then whether respondents "can get access to internet at home" and "use mobile internet" was chosen to represent the level of internet usage; the answer "Yes" is assigned " 1 " and the answer "No" is "O". "Social network" and 18 other kinds of network applications were used for evaluating residents' network application level; the answer "usually use" is valued " 1 ", "occasionally use" is " 0.5 " and "no use" is " 0 ".

(2) The intensity of activity. The intensity of an activity, reflecting the spatial distribution of residents' daily activities, is often closely related with the elemental flows and spatial mobility. The intensity of a physical activity has a close relationship with transportation accessibility, socioeconomic status and land use, and the intensity of a virtual activity reflects the information flows and the complexity of the spatial function. Based on the activity location obtained from the residents' activity diaries, the Kernel density method was adopted to analyse the density of activity on workdays and at the weekend. Thus, five times intensity of an activity on any given weekday, plus twice the intensity of an activity on a weekend makes the total intensity of activity.

(3) Spatial activeness. The spatial activeness, reflecting the condition of urban land use intensity and its dependent activities, can be expressed by analysing the scale of different types of construction land and the land use intensity within a certain spatial scope. Residential land, commercial land and industrial land are the main components of urban land use. The scale and intensity of these three land types represent the spatial activeness to a large extent (Xi et al., 2013). It is difficult to get data of land use intensity, so this study simplified the relative intensity of commercial land, residential land and industrial land to the values " 3 ", "2" and "1", correspondingly. Then, the land use intensity was counted on a GIS platform with the present land use data.

\subsubsection{Determining index weights}

The Analytic Hierarchy Process (AHP) was adopted to determine the index weights. On the basis of this index system, a fuzzy judgment matrix was constructed to calculate the relative weight of indices, with which the spatial mobility can be weighted. The processes are as follows:

(1) Establishing the hierarchy. According to the index system for evaluating the spatial mobility, the hierarchy was established, which took the intensity of spatial mobility and its degree of effect on the space of flows as the target layer. The spatial accessibility, intensity of activity and spatial activeness were set as the indices of the first level, and its corresponding indices of the second level were the transportation accessibility, informatization level, intensity of activity on workdays and at the weekend, and the intensity of land use.

(2) Constructing fuzzy judgment matrix. A proportional scale from 1 to 9 was used to evaluate the relative importance of the $i$ and $j$ index: 
Table 1. The meaning of proportional scale

\begin{tabular}{|c|c|c|c|c|c|c|}
\hline $\begin{array}{l}\text { Relative } \\
\text { importance }\end{array}$ & $\begin{array}{c}\text { Equal } \\
\text { importance }\end{array}$ & $\begin{array}{l}\text { Moderate } \\
\text { importance }\end{array}$ & $\begin{array}{l}\text { Obvious } \\
\text { importance }\end{array}$ & $\begin{array}{c}\text { High } \\
\text { importance }\end{array}$ & $\begin{array}{c}\text { Vital } \\
\text { importance }\end{array}$ & $\begin{array}{c}\text { The middle } \\
\text { value of } \\
\text { adjacent } \\
\text { judgment }\end{array}$ \\
\hline Value & 1 & 3 & 5 & 7 & 9 & $2,4,6,8$ \\
\hline
\end{tabular}

In formula (1), $a_{i j}$ is the relative importance of the comparison of $i$ index to $j$ index.

Then, a fuzzy judgment matrix was built as follows:

Table 2. The fuzzy judgment matrix

\begin{tabular}{lccc}
\hline & $\begin{array}{c}\text { Spatial accessibility } \\
\text { (a1) }\end{array}$ & $\begin{array}{c}\text { Intensity of activity } \\
\text { (a2) }\end{array}$ & $\begin{array}{c}\text { Spatial activeness } \\
\text { (a3) }\end{array}$ \\
\hline Spatial accessibility (a1) & 1 & $1 / 2$ & 2 \\
Intensity of activity (a2) & 2 & 1 & 3 \\
Spatial activeness (a3) & $1 / 2$ & $1 / 3$ & 1 \\
\hline
\end{tabular}

(3) Calculating the index weights. First, measuring the maximum eigenvalue of the judgment matrix, its corresponding characteristic vector $W$ was calculated. The component of $W\left(W_{1}, W_{2}, \ldots, W_{n}\right)$ is the relative importance of $n$ index, namely the coefficients of weight. Asymptotic Normalization Coefficient was used to calculate the weights. First of all, each column of the judgment matrix is normalized, then the judgment matrix is summed by rows, and the result of the summation is normalized for the characteristic vector.

$$
W=\left[W_{1}, W_{2}, \ldots, W_{n}\right]^{T}=[0.297,0.538,0.164]
$$

According to the single sorting of hierarchy, the judgment matrix meets the consistency check. So the index system and weights of spatial mobility are as follows:

Table 3. The index system and weights of spatial mobility

\begin{tabular}{|c|c|c|c|c|}
\hline $\begin{array}{l}\text { The first } \\
\text { level } \\
\text { indices }\end{array}$ & $\begin{array}{l}\text { The second } \\
\text { level indices } \\
\text { (weights) }\end{array}$ & \multicolumn{2}{|c|}{ The description of indices } & Assignment \\
\hline \multirow{10}{*}{$\begin{array}{c}\text { Spatial } \\
\text { accessibility } \\
(0.297)\end{array}$} & \multirow{6}{*}{$\begin{array}{c}\text { Transportation } \\
\text { accessibility } \\
(0.1485)\end{array}$} & \multirow{3}{*}{$\begin{array}{l}\text { The buffer } \\
\text { of railway } \\
\text { (subway) } \\
\text { station }\end{array}$} & $\begin{array}{c}\text { First class buffer of } \\
\text { railway (subway) station }\end{array}$ & 9 \\
\hline & & & $\begin{array}{l}\text { Second class buffer of } \\
\text { railway (subway) station }\end{array}$ & 5 \\
\hline & & & $\begin{array}{l}\text { Third class buffer of } \\
\text { railway (subway) station }\end{array}$ & 1 \\
\hline & & \multirow{3}{*}{$\begin{array}{c}\text { The buffer } \\
\text { of roads }\end{array}$} & $\begin{array}{c}\text { First class buffer of } \\
\text { roads }\end{array}$ & 9 \\
\hline & & & $\begin{array}{c}\text { Second class buffer of } \\
\text { roads }\end{array}$ & 5 \\
\hline & & & $\begin{array}{c}\text { Third class buffer of } \\
\text { roads }\end{array}$ & 1 \\
\hline & \multirow{4}{*}{$\begin{array}{c}\text { Informatization } \\
\text { level } \\
(0.1485)\end{array}$} & \multirow{3}{*}{$\begin{array}{l}\text { The usage } \\
\text { of } \\
\text { information } \\
\text { equipment }\end{array}$} & $\begin{array}{l}\text { Whether usually use } \\
\text { smart phone or not }\end{array}$ & $\begin{array}{l}\text { "Yes" is " } 1 " ; \\
\text { "No" is " } 0 \text { " }\end{array}$ \\
\hline & & & $\begin{array}{c}\text { Whether usually use } \\
\text { laptop or not }\end{array}$ & $\begin{array}{l}\text { "Yes" is " } 1 " ; \\
\text { "No" is " } 0 \text { " }\end{array}$ \\
\hline & & & $\begin{array}{l}\text { Whether usually use Pad } \\
\text { or not }\end{array}$ & $\begin{array}{l}\text { "Yes" is " } 1 " ; \\
\text { "No" is " } 0 \text { " }\end{array}$ \\
\hline & & & $\begin{array}{l}\text { Whether can get access } \\
\text { to internet at home }\end{array}$ & $\begin{array}{l}\text { "Yes" is " } 1 " ; \\
\text { "No" is " } 0 \text { " }\end{array}$ \\
\hline
\end{tabular}




\begin{tabular}{|c|c|c|c|c|}
\hline & & $\begin{array}{c}\text { The level of } \\
\text { internet } \\
\text { usage }\end{array}$ & $\begin{array}{l}\text { Whether to use mobile } \\
\text { internet }\end{array}$ & $\begin{array}{l}\text { "Yes" is " } 1 \text { "; } \\
\text { "No" is " } 0 \text { " }\end{array}$ \\
\hline & & $\begin{array}{l}\text { Network } \\
\text { application } \\
\text { level }\end{array}$ & $\begin{array}{l}\text { Whether usually use the } \\
\text { network application of } \\
\text { smart phone and } \\
\text { computer }\end{array}$ & $\begin{array}{c}\text { "usually use" } \\
\text { is " } 1 \text { ", } \\
\text { "occasionally } \\
\text { use" is " } 0.5 \text { " } \\
\text { and "no use" } \\
\text { is "0" }\end{array}$ \\
\hline \multirow{4}{*}{$\begin{array}{l}\text { Intensity of } \\
\text { activity } \\
(0.538)\end{array}$} & \multirow{2}{*}{$\begin{array}{c}\text { Intensity of } \\
\text { activity on } \\
\text { workday } \\
(0.384)\end{array}$} & \multirow{2}{*}{$\begin{array}{c}\text { Activities on } \\
\text { workday }\end{array}$} & Physical activities & $\begin{array}{c}\text { The intensity } \\
\text { of spatial } \\
\text { distribution }\end{array}$ \\
\hline & & & Virtual activities & $\begin{array}{c}\text { The intensity } \\
\text { of spatial } \\
\text { distribution }\end{array}$ \\
\hline & \multirow{2}{*}{$\begin{array}{c}\text { Intensity of } \\
\text { activity at } \\
\text { weekend } \\
(0.154)\end{array}$} & \multirow{2}{*}{$\begin{array}{c}\text { Activities at } \\
\text { weekend }\end{array}$} & Physical activities & $\begin{array}{c}\text { The intensity } \\
\text { of spatial } \\
\text { distribution }\end{array}$ \\
\hline & & & Virtual activities & $\begin{array}{c}\text { The intensity } \\
\text { of spatial } \\
\text { distribution }\end{array}$ \\
\hline \multirow{3}{*}{$\begin{array}{c}\text { Spatial } \\
\text { activeness } \\
(0.164)\end{array}$} & \multirow{3}{*}{$\begin{array}{l}\text { intensity of } \\
\text { land use } \\
(0.164)\end{array}$} & \multirow{3}{*}{$\begin{array}{l}\text { The type of } \\
\text { land use }\end{array}$} & Commercial land & 3 \\
\hline & & & Residential land & 2 \\
\hline & & & Industrial land & 1 \\
\hline
\end{tabular}

\section{RESULTS}

\subsection{The characteristics of spatial mobility}

Based on the three aspects of the spatial mobility evaluation and its weighted results, Figure 3 shows the overall spatial mobility in Nanjing . It can be seen that the highest spatial mobility is concentrated in the old city, especially in Xinjiekou and its surroundings are the maximum mobility areas. The old city is the traditional urban centre of Nanjing with higher construction density, and it also has the most developed transportation system and most agglomerated activities. Therefore, the transportation accessibility and the intensity of activity are quite excellent. All of these conditions bring about the highest spatial mobility for the old city of Nanjing, which means that the old city is still the agglomerated centre of element flows and plays an important role in the whole urban functional organization.

The spatial mobility in the inner cities of Nanjing, such as in Hexi new town, the Nanjing railway station area, Zhonghuamen area, Xiaolingwei area and other areas, is relatively high, and there can be found cluster nodes of mobility in these areas. Hexi is a newly built town, and residents' activity here is less than that in the old city, however, Hexi new town attracts a lot of young people with a higher informatization level. The transportation accessibility remains in a better condition in the Nanjing railway station area, and also in Zhonghuamen and other inner city areas, which supports the residents' activities and efficient element flows. Thus, the spatial mobility in the inner city is relatively high, as are the number of places in the inner city performing as the connectors between the old city, with intensified mobility, and the outer city, with lower mobility.

Meanwhile, the spatial mobility in parts of the outer city is also relatively high, these areas include Nanjing high speed rail station and its surroundings, Jiangning new town, Xianlin centre, Nanjing economic and technological development zone, and so on. With the spatial expansion of the Nanjing 
metropolitan area, these areas become new urban growth centres and undertake specific urban functions, such as the regional transportation function, urban technology innovation and education function, and so on. The development of these functions brings the aggregation of production and living activities, as well as the aggregation and expansion of element flows in the outer city of Nanjing, so several spatial mobility nodes are gradually forming. However, the rest of built-up areas and suburbs have the lowest mobility.

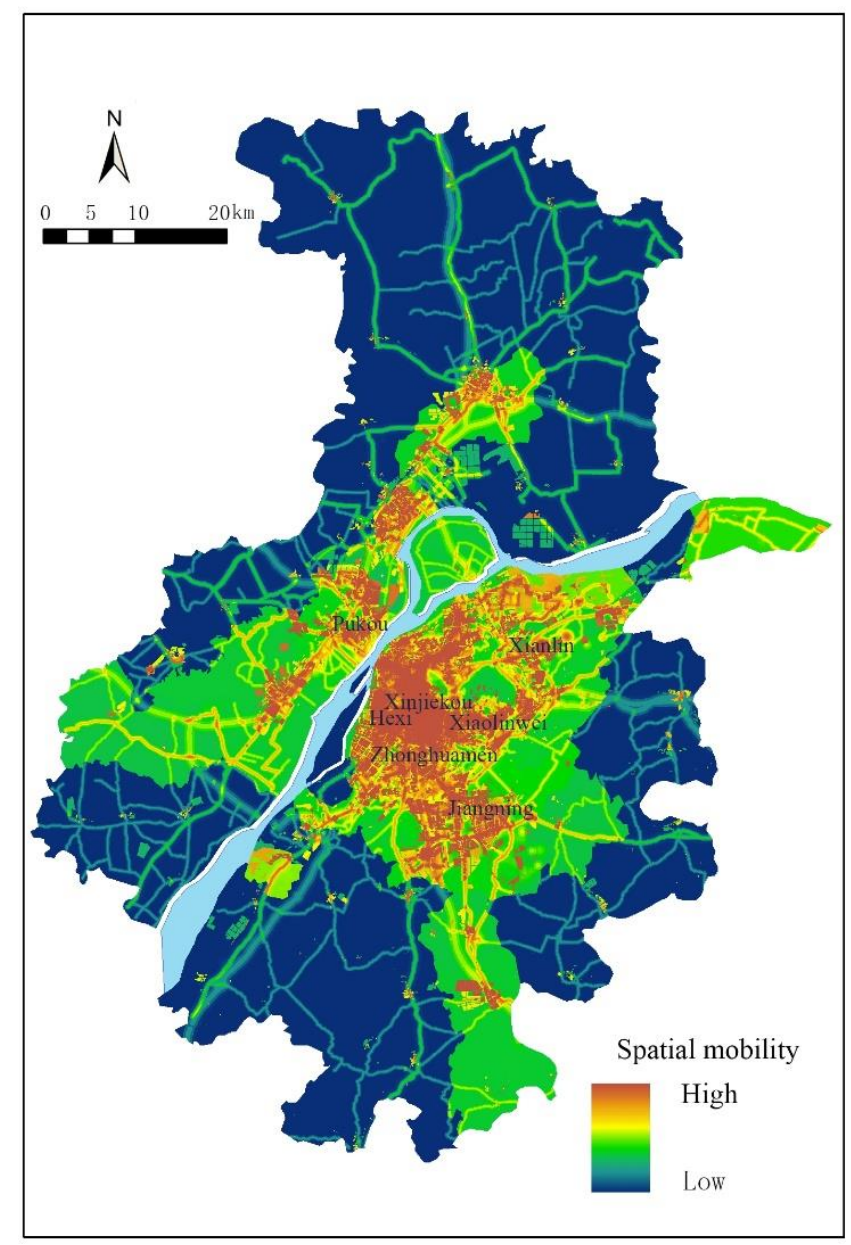

Figure 3. The distribution of spatial mobility in Nanjing

\subsection{The topological structure of urban space of flows}

The evaluation of the spatial mobility is an important approach to measure urban space of flows, which can be used to analyse the structure of urban space of flows through the intensity of the spatial mobility and connection direction of places. Based on the evaluated results of the spatial mobility, the topological structure of urban space of flows in Nanjing can be interpreted from five components (see Figure 4). 


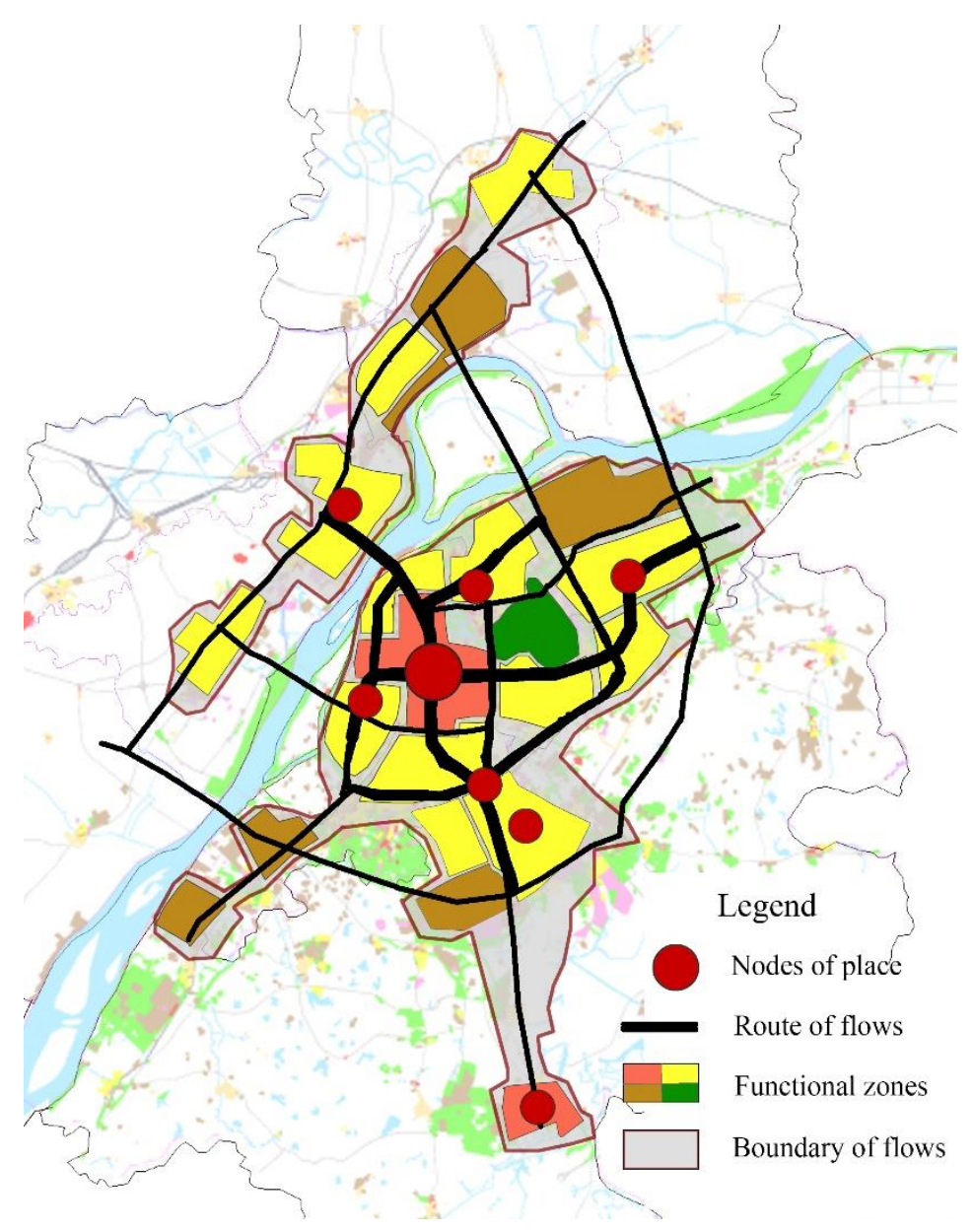

Figure 4. The topological structure of space of flows in Nanjing

\subsubsection{The nodes of place}

The primary activity centres constitute the nodes of place in the urban space of flows. The nodes of place with different scales, type and function have different effects on the elemental agglomeration and diffusion, which influences the interaction intensity between nodes of place. The old city of Nanjing is the most intensified mobility area with its developed transportation system and places of highly concentrated activity. Xinjiekou area is the core of the old city, which is treated as the Central Activity Zone (CAZ) of Nanjing (Wang, B. et al., 2015). It is also the central node in the Nanjing urban space of flows and plays a crucial role in the agglomeration and diffusion of the element flows generated by the enterprise and resident activity at the regional and metropolitan scales. Meanwhile, the higher mobility areas, such as Nanjing railway station, Nanjing high speed railway station, Xianlin centre, Hexi new town centre, Jiangning new town centre and Nanjing air harbour, are important nodes in the network of urban space of flows, and are also the places with the highest aggregated activity and active spaces.

The railway station and airport are the window nodes for Nanjing to connect to the global and regional space of flows, conversely, the localized accumulation of global and regional element flows enhances the function gathered in these transportation nodes and the appearance of new industrial zones (for example, high-speed rail business district, airport industrial district, and so on). The nodes of new town centres, formed in the process of suburbanization, are comprehensive places with business, catering, leisure, 
entertainment and other functions, which play a vital role in optimizing the spatial structure of new urban districts.

\subsubsection{The route of flows}

The direction of routes reflects the interactions between different places and the strength of routes reflects the interaction intensity between places and functional zones. The connection route of nodes and places in Nanjing's space of flows could be treated as a network structure with a 'ring and radial' pattern, which connects different types of functional zones and different scale nodes together.

The ring route of flows connects the functional zone and nodes of space of different urban layers together, and constitutes the channel of element flows for the inner city and the outer city in Nanjing. The inner ring route, supported by the express way around the outside of Nanjing inner city, connects Yuhuatai, Qinhuai, Xuanwu and other districts together, and is also the fast connection channel between the inner city and outer city. The element flows along that channel are intensified. The outer ring route, which is formed by the ring highway across the outer city, connects Xianlin, Jiangning, Pukou, Liuhe and other outer cities. Because the spatial mobility of Nanjing outer city is less intensified than that of the inner city and old city, so are the ring routes.

The radial routes are the important channels between the Xinjiekou CAZ and other urban areas. Several radial routes assemble in the old city to support the functioning agglomeration and diffusion of the CAZ. The radial routes of flows directed from the CAZ to newly built urban districts in the outer city are beneficial for transferring the elements of the old city to the suburbs, playing a positive role in the construction of functions and nodes in the suburban areas.

\subsubsection{The boundary of flows}

The boundary of flows is the result of the coupling of residents' daily activity, urban infrastructure construction and land use, and is closely related to urban spatial expansion and the urban growth boundary (UGB). The boundary of flows could be characterized by the recession of a region of spatial mobility. The boundary of Nanjing's space of flows is mainly distributed to the south of the Yangtze River, most of that being concentrated within the range inside the ring highway. The boundary range outside the ring highway extends to the southern part of the outer city until it reaches the airport zone. The boundary of flows takes the shape of a belt distribution along the north bank of the Yangtze River and covers Jiangpu Street, Dachang, Liuhe town and other functional zones. The boundary of flows could be considered as a flexible scope for UGB governance.

\subsubsection{The functional zones}

The functional zones can be divided into a comprehensive business district, residential district, recreation and leisure district, new industrial district, and so on. The old city of Nanjing is the main comprehensive business district and serves the metropolitan and wider regional area. Under the background of transformation development, the land use of the comprehensive business district in the old city has become even more mixed with the application of mobile information technologies and E-commerce, as well as the development of headquarters of economy and technological innovation. Meanwhile, its corresponding places have turned into more complex and flexible areas. The 
recreation and leisure zones (for example, Xuanwu lake scenic area, Zijin mountain scenic area, and so on) play an important role in improving urban quality. The new industrial districts are mainly distributed in the outer city of Nanjing, such as the economic and technological development area, software industrial park, et cetera. These new industrial districts are important spaces of places for Nanjing to participate in the international division of labour and to engage in element flows of global production. In all, the functional zones are the basic spatial form of the space of flows, and their combinations reflect the spatial relationship and interaction of socioeconomic activities, which also have an effect on the mobility of residential and enterprise activities.

\subsubsection{The network of flows}

The nodes and routes are the basic components of the network of flows, which can be treated as a combination of the public activity places, mobility support systems (for example, transportation system, information technologies, et cetera) and element flows. The network of flows in the information era is created by the agglomeration and interaction of residents' daily activities. Castells (1996) believed that the network in the space of flows was the spatial organization of the management elite, and the network of the management elite brought the imbalance of social organization. However, with the wide usage of information technologies, this space of flows is no longer a network by the organization of the management elite, but a connection network of urban residents' daily activities. The topological structure of the Nanjing space of flows takes on the characteristics of a flat network. On the one hand, the space of flows shows the scale-free network of cyberspace, on the other hand, it is embedded in the space of places and effected by the hierarchical system of places.

\section{CONCLUSION AND DISCUSSION}

Based on the new mobility paradigm of the information era, this paper put forward a new methodology to measure urban space of flows through evaluating spatial mobility. Urban space of flows have been considered as the coupling of technologies, activities, socio-economic factors and the physical environment. Following this, spatial mobility was taken as an important measurement for an evaluation of the urban space of flows. The evaluation model was structured from technological accessibilities, the intensity of activity and the spatial activeness. With the data of residential activity dairies and the data of Nanjing's traffic system and land use, a case study of Nanjing was undertaken to understand the topological structure of urban space of flows from the nodes of place, the route of flows, the boundary of flows, the functional zones and the network of flows.

The existing analyses of the space of flows mainly adopted the element flows to describe its structure from the perspective of the nodes and networks. Such research attempted to account for the global city network and regional space structure through analysing the macro-scale element flows (Sassen, 2001; Taylor et al., 2007). Substantially, it focused on the ideas of the production division of labour system and connecting networks in the context of globalization and informatization, and how the geographic embeddedness of mobility elements influenced the development of localization space (Reades \& 
Smith, 2014). However, the systematic analysis of the coupling of element flows and localization space is insufficient. The residential activity space becomes more and more important in shaping the urban spatial structure in information societies, so this paper evaluated spatial mobility considering the technological support interactions, residential activities and the space of places, and built a new methodology for measuring urban space of flows under the new mobility paradigm.

Based on the evaluation results of spatial mobility, the topological structure of Nanjing's space of flows was identified as the nodes of pubic activity, the routes and network of flows, and the functional zones. In addition, Xinjiekou is treated as the CAZ, and there are some other nodes of transportation and business in the inner and outer city. The boundary of flows is mainly confined to the main urban districts and most of the urban functional zones are distributed in these areas. The routes of the 'ring and radial' pattern connect the nodes of flows and the functional zones to form the network of Nanjing's space of flows. The empirical analysis could help to understand urban spatial structures from the system coupling of technologies, activities and environment in the information era, so as to improve the sustainability and coordination of urban space.

Studies on the spatial mobility and urban space of flows could help to guide the construction of physical space. Aimed at improving the spatial mobility of newly built urban districts, some policies should be implemented to reinforce the agglomeration of different element flows so as to advance the development quality of these zones. The mobility connections between the urban central district and urban fringe areas are through the application of intelligent transportation and other information technologies. On the one hand, in order to alleviate traffic congestion, environmental degradation and other urban diseases in central districts due to the highly concentrated and intensified land use, some element flows in urban central districts should be dispersed to urban fringe areas. On the other hand, the new nodes of a space of flows could be cultivated in the outer city and suburbs to optimize the layout of urban nodes of place and to realize the balanced development of an urban space.

The recording of activity diaries was completed by means of memory recollection, so the data is not as precise as expected. A more accurate data collecting approach (for example, using GPS, smart phone, et cetera) could be used to obtain the trajectory of residential activity (Lee \& Kwan, 2011). Although residential daily activities and people mobility have become the most important factors for the reconstruction of urban space, the production element flows still play a critical role in shaping the urban space of flows. It is necessary to explore more complex methods to analyse urban space of flows with the production element flows, residential daily activity and mobility, as well as other factors in future research.

\section{ACKNOWLEDGEMENTS}

This work was supported by the National Natural Science Foundation of China under Grant 41571146. 


\section{REFERENCES}

Alderson, A. S., \& Beckfield, J. (2004). "Power and Position in the World City System". American journal of sociology, 109(4), 811-851.

Alexander, B., Ettema, D., \& Dijst, M. (2010). "Fragmentation of Work Activity as a MultiDimensional Construct and Its Association with Ict, Employment and Sociodemographic Characteristics". Journal of Transport Geography, 18(1), 55-64.

Alexander, B., Hubers, C., Schwanen, T., Dijst, M., \& Ettema, D. (2011). "Anything, Anywhere, Anytime? Developing Indicators to Assess the Spatial and Temporal Fragmentation of Activities". Environment and Planning B: Planning and Design, 38(4), 678-705.

Bailey, R., Allen, J. K., \& Bras, B. (2004). "Applying Ecological Input-Output Flow Analysis to Material Flows in Industrial Systems: Part I: Tracing Flows". Journal of Industrial Ecology, 8(1-2), 45-68.

Bakis, H., \& Roche, E. M. (1997). "Cyberspace-the Emerging Nervous System of Global Society and Its Spatial Functions". In Roche, E. M. \& Bakis, H. (Eds.), Developments in Telecommunications. Between Global and Local. Brookfield, VT: Ashgate Publishing Company.

Beaverstock, J. V., Smith, R. G., Taylor, P. J., Walker, D., \& Lorimer, H. (2000). "Globalization and World Cities: Some Measurement Methodologies". Applied geography, 20(1), 43-63.

Bush, S. R., \& Oosterveer, P. (2007). "The Missing Link: Intersecting Governance and Trade in the Space of Place and the Space of Flows". Sociologia Ruralis, 47(4), 384-399.

Cairncross, F. (2001). The Death of Distance: How the Communications Revolution Is Changing Our Lives. Boston: Harvard Business Press.

Castells, M. (1989). The Informational City: Information Technology, Economic Restructuring, and the Urban-Regional Process. Oxford: Blackwell.

Castells, M. (1996). The Information Age: Economy, Society, and Culture Vol I - the Rise of the Network Society. Cambridge: Blackwell.

Castells, M. (2000). "Materials for an Exploratory Theory of the Network Society1". The British journal of sociology, 51(1), 5-24.

Castells, M. (2005). "Space of Flows, Space of Places: Materials for a Theory of Urbanism in the Information Age". In Bishwapriya, S. (Ed.), Comparative Planning Cultures. New York: Routledge.

Couclelis, H. (2000). "From Sustainable Transportation to Sustainable Accessibility: Can We Avoid a New Tragedy of the Commons?". In Janelle, D. G. \& Hodge, D. C. (Eds.), Information, Place, and Cyberspace (pp. 341-356). Berlin: Springer.

Couclelis, H. (2004). "Pizza over the Internet: E-Commerce, the Fragmentation of Activity and the Tyranny of the Region". Entrepreneurship \& Regional Development, 16(1), 41-54.

Derudder, B., \& Witlox, F. (2005). "An Appraisal of the Use of Airline Data in Assessing the World City Network: A Research Note on Data". Urban Studies, 42(13), 2371-2388.

Dong, C., Xiu, C. L., \& Wei, Y. (2014). "Network Structure of 'Space of Flows' in Jilin Province Based on Telecommunication Flows". Acta Geographica Sinica, 69(4), 510-519.

e Silva, A. S. (2006). "From Cyber to Hybrid Mobile Technologies as Interfaces of Hybrid Spaces". Space and culture, 9(3), 261-278.

Graham, S. (2004). The Cybercities Reader. London: Routledge.

Graham, S., \& Marvin, S. (2001). Splintering Urbanism: Networked Infrastructures, Technological Mobilities and the Urban Condition. London: Routledge.

Hägerstraand, T. (1970). "What About People in Regional Science?". Regional Science, 24(1), 7-24.

Hall, P. G., \& Pain, K. (2006). The Polycentric Metropolis: Learning from Mega-City Regions in Europe. London: Earthscan Publications.

Harvey, D. (1989). The Condition of Postmodernity: An Enquiry into the Origins of Cultural Change. Cambridge: Blackwell.

Hjorthol, R., \& Gripsrud, M. (2009). "Home as a Communication Hub: The Domestic Use of Ict". Journal of Transport Geography, 17(2), 115-123.

Kellerman, A. (2010). "Mobile Broadband Services and the Availability of Instant Access to Cyberspace". Environment and planning A, 42(12), 2990-3005.

Kitchin, R. (1997). "Social Transformations through Spatial Transformations: From 'Geospaces' to 'Cyberspaces'". In Behar, J. E. (Ed.), Mapping Cyberspace: Social Research on the Electronic Frontier (pp. 149-173). New York: Dowling College Press.

Kwan, M. P. (2004). "Gis Methods in Time-Geographic Research: Geocomputation and Geovisualization of Human Activity Patterns". Geografiska Annaler: Series B, Human Geography, 86(4), 267-280. 
Kwan, M. P. (2013). "Beyond Space (as We Knew It): Toward Temporally Integrated Geographies of Segregation, Health, and Accessibility: Space-Time Integration in Geography and Giscience". Annals of the Association of American Geographers, 103(5), 1078-1086.

Lee, J. Y., \& Kwan, M. P. (2011). "Visualisation of Socio-Spatial Isolation Based on Human Activity Patterns and Social Networks in Space-Time". Tijdschrift voor economische en sociale geografie, 102(4), 468-485.

Leng, B. R., \& Yang, Y. C. (2012). Network Growth: From Network Studies to City Network. Lanzhou: Lanzhou University press.

Li, J. (2011). Global Production Networks and Spatial Organization of Production in Metropolitan Areas. Beijing: Science Press.

Maeng, D.-M., \& Nedović-Budić, Z. (2008). "Urban Form and Planning in the Information Age: Lessons from Literature". Spatium, (17-18), 1-12.

Malecki, E. J. (2002). "The Economic Geography of the Internet's Infrastructure". Economic Geography, 78(4), 399-424.

Mokhtarian, P. L. (1990). "A Typology of Relationships between Telecommunications and Transportation". Transportation Research Part A: General, 24(3), 231-242.

O'Brien, R. (1992). Global Financial Integration: The End of Geography. London: Council on Foreign Relations Press.

Ohmori, N., \& Harata, N. (2008). "How Different Are Activities While Commuting by Train? A Case in Tokyo". Tijdschrift voor economische en sociale geografie, 99(5), 547-561.

Reades, J., \& Smith, D. A. (2014). "Mapping the 'Space of Flows': The Geography of Global Business Telecommunications and Employment Specialization in the London Mega-CityRegion". Regional Studies, 48(1), 105-126.

Salomon, I. (1986). "Telecommunications and Travel Relationships: A Review". Transportation Research Part A: General, 20(3), 223-238.

Sassen, S. (2001). The Global City: New York, London, Tokyo. Princeton: Princeton University Press.

Shen, L. Z. (2010). Space of Flow. Nanjing: Southeast University Press.

Smith, D. A., \& Timberlake, M. (1995). "Conceptualising and Mapping the Structure of the World System's City System". Urban Studies, 32(2), 287-302.

Sokol, M. (2007). "Space of Flows, Uneven Regional Development, and the Geography of Financial Services in Ireland". Growth and Change, 38(2), 224-259.

Taylor, P. J. (2004a). "The New Geography of Global Civil Society: Ngos in the World City Network". Globalizations, 1(2), 265-277.

Taylor, P. J. (2004b). World City Network: A Global Urban Analysis. London: Routledge.

Taylor, P. J., Derudder, B., Saey, P., \& Witlox, F. (2007). Cities in Globalization: Practices, Policies and Theories. London: Routledge.

Urry, J. (2000). Sociology Beyond Societies: Mobilities for the Twenty-First Century. London: Routledge.

Urry, J. (2008). "Moving on the Mobility Turn". In Canzler, W., Kaufmann, V., \& Kesselring, S. (Eds.), Tracing Mobilities: Towards a Cosmopolitan Perspective. Aldershot: Ashgate.

Wang, B., Zhen, F., Wei, Z., Guo, S., \& Chen, T. (2015). "A Theoretical Framework and Methodology for Urban Activity Spatial Structure in E-Society: Empirical Evidence for Nanjing City, China". Chinese Geographical Science, 25(6), 672-683.

Wang, D. G., \& Law, F. Y. T. (2007). "Impacts of Information and Communication Technologies (Ict) on Time Use and Travel Behavior: A Structural Equations Analysis". Transportation, 34(4), 513-527.

Wilson, M. W., \& Graham, M. (2013). "Situating Neogeography". Environment and planning A, 45(1), 3-9.

Wu, K., Fang, C. L., \& Zhao, M. X. (2013). "The Intercity Space of Flow Influenced by HighSpeed Rail: A Case Study for the Rail Transit Passenger Behavior between Beijing and Tianjin". Acta Geographica Sinica, 68(2), 159-174.

Xi, G. L., Zhen, F., Shen, L. Z., \& Wang, B. (2013). "The Evaluation of Resident Fluidity and the Spatial Characteristics of Flow in Nanjing". Scientia Geographica Sinica, 33(9), 10511057.

Zhao, Y., \& Chai, Y. W. (2013). "Residents' Activity-Travel Behavior Variation by Communities in Beijing, China". Chinese Geographical Science, 23(4), 492-505.

Zhen, F., Wang, X., Yin, J., \& Zhang, M. (2013). "An Empirical Study on Chinese City Network Pattern Based on Producer Services". Chinese Geographical Science, 23(3), 274285.

Zhen, F., \& Wei, Z. C. (2008). "Influence of Information Technology on Social Spatial Behaviors of Urban Residents-Case of Nanjing City in China". Chinese Geographical Science, 18(4), 316-322. 